Article

\title{
Productivity, Profitability and Nitrogen Utilisation Efficiency of Two Pasture-Based Milk Production Systems Differing in the Milking Frequency and Feeding Level
}

\author{
Martín Correa-Luna ${ }^{1, *(\mathbb{D}}$, Daniel Donaghy ${ }^{1}$, Peter Kemp ${ }^{1}{ }^{(0)}$, Laurence Shalloo ${ }^{2}$, Elodie Ruelle ${ }^{2}(\mathbb{D}$, \\ Deirdre Hennessy ${ }^{2}$ (D) and Nicolás López-Villalobos ${ }^{1}$ (i) \\ 1 School of Agriculture and Environment, Massey University, Private Bag 11-222, \\ Palmerston North 4410, New Zealand; d.j.donaghy@massey.ac.nz (D.D.); p.kemp@massey.ac.nz (P.K.); \\ n.lopez-villalobos@massey.ac.nz (N.L.-V.) \\ 2 Teagasc, Animal and Grassland Research and Innovation Centre, Moorepark, Fermoy, \\ P61 P302 Co. Cork, Ireland; laurence.shalloo@teagasc.ie (L.S.); elodie.ruelle@teagasc.ie (E.R.); \\ deirdre.hennessy@teagasc.ie (D.H.) \\ * Correspondence: martin.correa.luna@gmail.com
}

check for updates

Citation: Correa-Luna, M.; Donaghy, D.; Kemp, P.; Shalloo, L.; Ruelle, E.; Hennessy, D.; López-Villalobos, N. Productivity, Profitability and Nitrogen Utilisation Efficiency of Two Pasture-Based Milk Production Systems Differing in the Milking Frequency and Feeding Level. Sustainability 2021, 13, 2098. https://doi.org/10.3390/su13042098

Academic Editor: Sean Clark Received: 30 December 2020 Accepted: 13 February 2021 Published: 16 February 2021

Publisher's Note: MDPI stays neutral with regard to jurisdictional claims in published maps and institutional affiliations.

Copyright: (c) 2021 by the authors. Licensee MDPI, Basel, Switzerland. This article is an open access article distributed under the terms and conditions of the Creative Commons Attribution (CC BY) license (https:// creativecommons.org/licenses/by/ $4.0 /)$.

\begin{abstract}
The aim of this study was to model the productivity, profitability and the nitrogen (N) utilisation efficiency (NUE) of two spring-calving pasture-based milk production systems differing in milking frequency and intensification levels in New Zealand. For this purpose, physical performance data from a low-intensity production system where cows were milked once per day (OAD-LI) and from a high-intensity production system where cows were milked twice per day (TAD-HI) were employed. OAD-LI cows were milked once-daily with a stocking rate (SR) of 2.1 cows/ha and fed diets with low supplementation (304 kg pasture silage/cow) with applications of $134 \mathrm{~kg} \mathrm{~N}$ fertiliser/ha and TAD-HI cows were milked twice-daily with a SR of 2.8 cows/ha and fed diets of higher supplementation (429 kg pasture silage and $1695 \mathrm{~kg}$ concentrate/cow) with applications of $87 \mathrm{~kg} \mathrm{~N}$ fertiliser/ha. The Moorepark Dairy System Model was used to evaluate production, economic performance and $\mathrm{N}$ balance on an annual basis. Despite the higher feed costs of TAD-HI as more supplementation was utilised, profitability per hectare was $16 \%$ higher because more cows were milked with a higher milk yield per cow (milking frequency) when compared to OAD-LI. At the cow level, the NUE was higher in TAD-HI ( $30 \%$ vs. $27 \%$ ) reflecting the better balanced diet for energy and crude protein and higher milk yields as a result of milking frequency. At the farm scale the NUE was higher ( $38 \%$ vs. $26 \%$ ) in the TAD-HI due to the losses associated with the imported feed being excluded and higher $\mathrm{N}$ captured in milk. These results suggest that milking frequency, the use of feed supplementation and application of $\mathrm{N}$ fertiliser as management tools on grazing dairy systems affect productivity, profitability and $\mathrm{N}$ balance. Further studies are required to find optimal stocking rates in combination with the use of supplementary feed and $\mathrm{N}$ fertiliser application that maximize milk production and profitability for OAD and TAD milking production systems but minimize $\mathrm{N}$ losses.
\end{abstract}

Keywords: milk production; intensification; profitability; nitrogen use efficiency; sustainability

\section{Introduction}

Milk production from grasslands makes extensive use of ecosystem services, taking advantage of the high efficiency of ruminants to convert low-quality forage into dairy products of high-value protein for human consumption [1] while simplifying many of the issues related to handling wastes produced by animals when compared to confinement production systems [2]. Also, grazing systems are socially well perceived because they are associated with better animal welfare when compared to housed systems [3]. However, grazed pastures of New Zealand and other temperate regions are high in crude protein $(\mathrm{CP}$; nitrogen $(\mathrm{N})$ concentration $\times 6.25)$ concentration in early spring and late autumn, at 
levels that regularly exceed milk production requirements [1,4]. This results in more $\mathrm{N}$ excreted and a decrease in N utilisation efficiency (NUE) at the cow level, defined in this case as $\mathrm{N}$ captured in milk and meat as a proportion of total $\mathrm{N}$ intake. Considering that in these systems cows are raised outdoors all year round, most of their excreta is returned to pasture, and this increases the nitrate-N levels in soil solution and groundwater. This is an important environmental problem, as well as being wasteful in terms of utilisation of plant nutrients [5,6].

Driven by increasing global food demand, New Zealand farmers have steadily increased milk production since the 1990s through intensification including an increase in number of cows per farm, the use of $\mathrm{N}$ fertiliser to boost pasture production and incorporation of supplementary feed, mainly to meet the increase in feed demand as a consequence of an increase in cow numbers, but also to extend lactation length and pasture harvest. Associated with this intensification process, there is a reduction in whole-farm NUE and a concomitant increase in $\mathrm{N}$ losses from the farm, which is directly recognised as a source of environmental pollution [5-7].

In contrast to the majority of farmers milking cows twice-daily (TAD) in New Zealand, some are adopting once-daily (OAD) milking throughout a full lactation as a production system to reduce production costs [8]. A OAD production system is typically associated with lower intensification, especially lower use of supplementary feeds, and reduced labour [9]. Although previous research analysing OAD production systems focused on animal performance and economic outcomes $[8,10,11]$, the existing research dedicated to assessing aspects of the environmental implications of OAD production systems [12] did not include NUE analysis at both the cow and farm level, and the existing research dedicated to evaluate the NUE of OAD vs. TAD was done only at the cow level [13]. Thus, the aim of the present study was to compare a OAD low intensity production system (i.e., cows milked OAD with lower supplementation) versus a TAD high intensity production system (i.e., cows milked TAD with higher supplementation) in terms of NUE and the $\mathrm{N}$ balance and losses on a cow and farm level, along with productivity and financial performance.

\section{Materials and Methods}

The present study was carried out from physical performance data originated from June 2016 to May 2017 on two contiguous research dairy farms located in the lower North Island of New Zealand (longitude $175^{\circ}$, latitude $-40^{\circ}$ ).

\subsection{Production Systems}

The OAD low intensity production system (OAD-LI) had a stocking rate (SR) of 2.1 cows/ha with cows milked OAD at 06:30 throughout the season. Feeding strategy included fresh ryegrass (Lolium perenne)/ white clover (Trifolium repens) pasture (hereafter referred to as pasture) as the main diet component, with the sporadic use of supplementation and grazing summer crops according to pasture availability. The herd comprised 66 Holstein-Friesian, 55 Jersey and 136 crossbred cows. During June, 58\% of the herd was wintered on the dry-stock unit prior to calving. Calving commenced on July 11th and continued up to October 3rd. From June to the calving date, pregnant dry cows on farm were feed-restrained and had access to daily strips of pasture at an allowance of approximately $5.5 \mathrm{~kg}$ dry matter (DM) and $2 \mathrm{~kg}$ DM of pasture hay per day which were offered on the paddock. After calving, milking cows had access as a single group to a new pasture paddock after each milking. From December to March and in April, a herb crop [mix of plantain (Plantago lanceolata), chicory (Cichorium intybus) and red clover (Trifolium pratense)] was grazed at an allowance of $3.5 \mathrm{~kg}$ DM per cow per day. In March and May, lucerne (Medicago sativa) was grazed at an allowance of $3 \mathrm{~kg}$ DM per cow per day. Turnips (Brassica campestris ssp. rapifera) were grazed at an allowance of $2.6 \mathrm{~kg}$ DM per cow per day only in February. Pasture silage was fed directly on the paddock in August and from March to May at a rate of $3.5 \mathrm{~kg}$ DM per cow per day. 
The TAD high intensity production system (TAD-HI) was managed at a SR of 2.8 cows/ha with cows milked TAD throughout the season, and higher supplementation level was included throughout the year. The herd comprised 52 Holstein-Friesian and 156 crossbred cows. During June, $42 \%$ of the total cows were allocated off farm. Calving commenced on July 1st and continued up to September 26th. Cows were milked daily at 05:30 and 14:30 throughout the season. From June to calving date, pregnant dry cows on farm had access as a single group to daily strips of pasture at an allowance of approximately $6 \mathrm{~kg} \mathrm{DM}$ per cow and $2 \mathrm{~kg}$ DM of pasture hay per day were offered on the paddock. After calving, milking cows had access as a herd to a new pasture paddock after each milking. During the lactation, maize (Zea mays) silage was fed before the afternoon milking on the feed pad at an average rate of $2.4 \mathrm{~kg}$ DM per cow per day and grain-based concentrate was fed during the morning milking inside the parlour at an average rate of $2 \mathrm{~kg}$ DM per cow per day. Pasture silage was fed directly on the paddock from July to September and from November to February at a rate of $1 \mathrm{~kg}$ DM per cow per day. In February and from April to May, pasture silage was fed directly on the paddock at a daily allowance of $0.5 \mathrm{~kg}$ DM per cow and tapioca (Manihot esculenta) pellets were fed at a daily allowance of $1 \mathrm{~kg}$ DM per cow. Molasses was fed inside the parlour at an allowance of $0.25 \mathrm{~kg}$ per cow per day during the lactation. From February to May, dried distillers grain was fed inside the parlour at an allowance of $0.6 \mathrm{~kg}$ per cow per day. Turnips were grazed at an allowance of $2.6 \mathrm{~kg}$ DM per cow in February and March. Table 1 presents the biophysical input data sourced from these two research dairy farms.

Table 1. Default biophysical production system characteristics and parameters of two contrasting pasture-based dairy production systems in New Zealand utilised in the Moorepark Dairy Systems Model ${ }^{1}$.

\begin{tabular}{ccc}
\hline & \multicolumn{2}{c}{ Production System $^{2}$} \\
\cline { 2 - 3 } Item & OAD-LI & TAD-HI \\
\cline { 2 - 3 } Farm size, ha & 120 & 92 \\
Milking cows & 257 & 257 \\
Average cow genetic merit $(\$ B W)^{3}$ & 87 & 82 \\
Stocking rate, milking cows/ha & 2.1 & 2.8 \\
Milk yield per cow, kg/cow & 4526 & 5910 \\
Milksolids yield per cow, kg/cow & 384 & 422 \\
Milk fat, \% & 5.54 & 4.54 \\
Milk protein, $\%$ & 4.22 & 3.68 \\
Milk lactose, \% & 5.15 & 5.64 \\
Length of lactation, days & 272 & 271 \\
Replacement rate, \% & 18.3 & 20.0 \\
Grazed pasture intake, kg DM/cow per year & 3427 & 3115 \\
Pasture silage intake, kg DM/cow per year & 304 & 429 \\
Concentrate intake, kg DM/cow per year & - & 1695 \\
Crops intake, kg DM/cow per year & 234 & 20 \\
Average live weight, kg & 486 & 507 \\
\hline
\end{tabular}

${ }^{1}$ Shalloo et al. [14]. ${ }^{2}$ Once-daily milking low intensity (OAD-LI); twice-daily milking high intensity (TAD-HI) ${ }^{3}$ Breeding worth, \$ (May 2017).

\subsection{Grazing Management and Mating Strategy}

Grazing management decision rules of pasture across the two farms were the same. Rotational grazing was practiced, and swards were strip grazed using temporary electric fences with fresh herbage offered daily after each milking. Targeted pre- and post-grazing pasture cover was determined by weekly monitoring of farm RGWC pasture covers following the guidelines of DairyNZ [15]. Pasture surplus to requirements was conserved as silage when growth rates exceeded cow requirements.

Both farms used common sires to inseminate all the cows in order to ensure that the replacement heifers were of higher merit for farm profit than the culled cows. The selection 
of sires was based on a breeding worth index (BW), which is calculated as the sum of the breeding values for lactation yields of milk, fat, and protein, cow live weight (LW), somatic cell count, fertility, survival and body condition score, each weighted by the corresponding economic values of each trait [16]. The BW index ranks the animals in units of net profit expressed in dollars per 5 tonnes of dry matter intake (DMI). Some particular sires were selected for No. 1 dairy farm for superior breeding values for udder conformation (udder support and front and rear teat placement) required for OAD milking.

\subsection{Animal Measurements}

After milking, all cows passed through an automatic race walkover scale (WoW xR3000 Tru-Test Ltd. Auckland, New Zealand) in order to generate daily LW records per cow. Individual yields of milk, fat, protein and milksolids (fat + protein), along with somatic cell count, were determined in monthly herd tests during the lactation using a Fossomatic FT120 (Foss Electric, Hillerød, Denmark).

\subsection{Feed Quality Measurements}

Apparent pasture intake (kg DM per cow per day) was calculated from pasture disappearance by measuring pre- and post-grazing masses on the grazing area assigned divided by the total number of cows. Pre- and post-grazing pasture RGWC covers were measured with a rising-plate meter (Jenquip, New Zealand) and estimated using the following New Zealand national calibration equation for pasture RGWC $[\mathrm{kg}$ DM/ha $=$ $140 \times$ compressed height +500 ] [17]. Estimated crop eaten was calculated as crop mass pre-grazing minus crop mass post-grazing, measured by harvesting three $0.1 \mathrm{~m}^{2}$ quadrats to ground level within the area allocated to cows on a daily basis. These measurements enabled calculation of apparent pasture and crop utilisation, and also the proportion of herbage allocated to cows before each herd test.

In the period of $24 \mathrm{~h}$ prior to each monthly herd test at 09:00 am, all feed ingredients offered to cows were sampled before feeding to measure their chemical composition. Fresh pasture and crop samples (approximately $1500 \mathrm{~g}$ of wet weight) were harvested using the hand-plucking method [18] from about 50 sites along the same transect that pre-grazing pasture mass was measured, to mimic herbage grazed by cows. Samples of maize and pasture silage were taken from the bunker and samples of grain-based concentrate, tapioca pellets and dried distillers grains were taken directly from the feeders during milking time. Samples of pasture hay and silage were collected directly from the paddock. All the samples were freeze-dried and ground (Wiley mill) to pass through a $1.0 \mathrm{~mm}$ screen. The levels of ash, CP, lipid, neutral detergent fibre, acid detergent fibre, organic matter digestibility, metabolisable energy (ME) and starch and soluble sugars were estimated by near infrared reflectance spectrometry [19] using a Bruker MPA near infrared reflectance spectrophotometer (Ettlingen, Germany) and are presented in Table 2. Calibrations for each component had been previously developed (Massey University Nutrition Laboratory, Palmerston North, New Zealand).

Table 2. The proportions of feed ingredients, and dietary chemical composition, fed on an annual basis in two contrasting pasture-based dairy production systems in New Zealand.

\begin{tabular}{ccc}
\hline & \multicolumn{2}{c}{ Production System $^{\mathbf{1}}$} \\
\cline { 2 - 3 } Item & OAD-LI & TAD-HI \\
\hline Diet ingredient, \% of total feed offered & & 60.2 \\
Pasture grazed & 89.2 & 2.7 \\
Pasture hay & 3.3 & 6.3 \\
Pasture silage & 2.8 & 1.3 \\
Pasture baleage & - & 1.1 \\
Brassica crop & 0.6 & - \\
Herb-mix crop & 3.2 & \\
\hline
\end{tabular}


Table 2. Cont.

\begin{tabular}{ccc}
\hline & \multicolumn{2}{c}{ Production System $^{\mathbf{1}}$} \\
\cline { 2 - 3 } Item & OAD-LI & TAD-HI \\
\hline Lucerne crop & 0.9 & - \\
Maize Silage & - & 13.1 \\
Concentrate & - & 11.6 \\
Tapioca pellets & - & 1.5 \\
Molasses & - & 1.2 \\
Dried distillers grains & - & 1.0 \\
Dietary chemical composition & & 10.66 \\
Feed energy content, MJ ME/kg DM & 10.87 & 15.12 \\
Crude protein, \% of DM & 19.54 & 0.71 \\
Energy:Crude Protein ratio, MJ ME/kg DM to CP\% & 0.56 & 22.49 \\
Acid detergent fibre, \% of DM & 22.88 & 41.66 \\
Neutral detergent fibre, \% of DM & 44.58 & 74.62 \\
Organic matter digestibility, \% of DM & 74.25 & \\
\hline
\end{tabular}

${ }^{1}$ Once-daily milking low intensity (OAD-LI); twice-daily milking high intensity (TAD-HI).

\subsection{Nitrogen Utilisation Efficiency Model Description}

The $\mathrm{N}$ balance model developed by Ryan et al. [20] was used to assess the NUE, N surplus and $\mathrm{N}$ losses on both farms at both the cow and the whole-farm level. At the cow level, the $\mathrm{N}$ balance model accounted for the partition of $\mathrm{N}$ excreta by back-calculating from the total $\mathrm{N}$ intake per cow, the proportions of $\mathrm{N}$ allocated into milk, maintenance and LW variation. The model estimates partition of $\mathrm{N}$ into urine by subtracting $\mathrm{N}$ in faeces from total excreta $\mathrm{N}$ calculated using the equation described by del Prado et al. [21]:

$$
\mathrm{N} \text { in dairy cow dung }(\mathrm{kg} \mathrm{N} / \text { cow year })=0.15 \times \mathrm{N}_{\text {animal intake }}+28.47
$$

where $\mathrm{N}_{\text {animal intake }}$ corresponds to the total intake of $\mathrm{N}$ during the year. In turn, these $\mathrm{N}$ sinks at the cow level were scaled up to the farm level considering total cows farmed per month in order to implement the whole-farm $\mathrm{N}$ balance as well as the overall balance on a per hectare basis.

The whole-farm $\mathrm{N}$ balance considers all $\mathrm{N}$ imported and exported from the milking platform. Imports and exports of $\mathrm{N}$ are conditional to temporary movement within diverse sinks of $\mathrm{N}$ (fertilisers, soil N, pasture, supplements imported, cow, milk and meat, excreta) and it can be expressed per $\mathrm{kg}$ of $\mathrm{N}$ per hectare or per cow. In the present study, it was considered that slurry was exported from both farms. Nitrogen fertiliser was applied as urea $(46 \% \mathrm{~N})$ to the pasture swards after grazing. In OAD-LI, $\mathrm{N}$ was applied 9 times at a rate of $18 \mathrm{~kg} \mathrm{~N}$ per ha to sustain high demand of pasture which was the main component in the ration. In TAD-HI, $\mathrm{N}$ was applied 6 times at a rate of $15 \mathrm{~kg} \mathrm{~N}$ per ha, the lower rate reflecting less pasture required in the diet as a consequence of higher supplementation. Values of $\mathrm{N}$ contained in different feed sources were calculated using the $\mathrm{CP}$ collected from the feed quality analysis divided by 6.25 to estimate $\mathrm{N}$ imports in each farm (note the $\mathrm{N}$ imports included in the feeds brought onto the farm did not include the $\mathrm{N}$ losses associated with growing the crops, which underestimates the $\mathrm{N}$ associated with imported feeds). Nitrogen output on the whole-farm level was comprised of two categories: $\mathrm{N}$ included in saleable products (livestock sales and milk) and $\mathrm{N}$ losses from the farm. Nitrogen lost through volatilisation was estimated using the equation by Misselbrook et al. [22]:

$$
\text { Ammonia emissions }\left(\mathrm{g} \mathrm{NH}_{3}-\mathrm{N} / \text { cow per day }\right)=-0.51+0.0742 \mathrm{~N}_{\text {fert }} \times \mathrm{SR}
$$

where $\mathrm{N}_{\text {fert }}$ corresponds to the input of fertiliser $\mathrm{N}(\mathrm{kg} \mathrm{N} /$ ha per year). The $\mathrm{N}$ balance model developed by Ryan et al. [18] reports estimated values of $\mathrm{N}$ leaching (kg N/ha) by using soil-type specific fractions for UK conditions. In their study, the $\mathrm{N}$ leaching estimations were validated with field measurements. Since it was not possible to validate 
the $\mathrm{N}$ leaching figures reported from the simulation in the present study, only values of $\mathrm{N}$ available for leaching are reported. This indicator is estimated as the remaining proportion of $\mathrm{N}$ inputs (e.g., fertiliser, excreta) after the $\mathrm{N}$ uptake by pastures and crops in each scenario. Nitrogen utilisation efficiency was estimated as the proportion of $\mathrm{N}$ recovered in milk and meat products as a proportion of total imported $\mathrm{N}$ at both the cow and whole-farm level.

\subsection{Economic Analysis}

The production and economic performance were modelled with the Moorepark Dairy System Model (MDSM, [14]) allowing the analysis of the biological, technical and physical processes along with farm profitability in each production system (PS). This whole-farm budgetary simulation model runs on an annual or monthly basis and integrates animal performance, pasture production and utilisation inventory, valuation and sales, milk production and sales, labour utilisation and feed requirements. In this model, values of net energy requirements for maintenance, pregnancy, production and daily LW variation were based on the French net energy system where 1 unité fourragère lait is the net energy requirement for lactation equivalent to $1 \mathrm{~kg}$ of standard air-dried barley [23], equivalent to $7.11 \mathrm{MJ}$ of net energy or $11.85 \mathrm{MJ}$ of ME. In turn, apparent DMI (kg DM/cow) was estimated based on total net energy requirements for maintenance, pregnancy, production and daily LW variation, divided by the net energy/ME content of any feed offered. Grass utilisation was calculated considering pasture grazed and harvested for silage making from total pasture production throughout the period considered in the present study. Feed requirements for maintenance and milk production achieved on specific supplementary feed and crop allowance, along with LW and LW variation from each herd, were used to estimate total pasture eaten.

In order to run the comparison between production systems, the farming area of both scenarios was unchanged but the TAD-HI herd size was increased to 257 milking cows, resulting in 257 cows in each herd with 120 and 92 ha in OAD-LI and TAD-HI, respectively. Farm operating profitability was determined by sales of milk and meat minus fixed and variable costs using the MDSM applied to the biophysical and economic data collected from information provided by the Massey University farms for the time of the experiment. Where inputs could not be determined separately for each farm, average values were utilised based on an economic survey by DairyNZ [17] according to each production system.

The MDSM calculates the economic performance subtracting the fixed costs (car use, electricity, labour, machinery maintenance and running costs, telephone costs and insurance costs), and the variable costs (concentrate supplementation, fertiliser, contractor expenses, veterinary costs and purchases of livestock) from total sales of both milk and meat, with all values expressed in NZ\$. Pasture growth rates and production of each farm utilised in the MDSM were calculated from assessing individual DM yield of paddocks. Table 3 summarises the financial parameters utilised in the modelling analysis. The workload for a single worker was assumed at $2466 \mathrm{~h}$ in OAD-LI and at $3147 \mathrm{~h}$ in TAD-HI with 1.3 and 1.44 farm staff for OAD-LI and TAD-HI, respectively.

\section{Results}

\subsection{Moorepark Dairy Systems Model Outputs for the Production Systems}

The productive performance of each production system is summarised in Table 4. Cows in OAD-LI had $23 \%$ lower milk production than cows in TAD-HI, representing $1384 \mathrm{~kg}$ of milk less per cow. Considering the different SR, milk production per ha was $41 \%$ higher in TAD-HI when compared to OAD-LI, representing $6817 \mathrm{~kg}$ of additional milk per ha in TAD-HI. Compared to TAD-HI, milksolids yield was $9 \%$ less per cow and $30 \%$ less per ha in OAD-LI. 
Table 3. Default financial parameters ${ }^{1}$ used in the Moorepark Dairy Systems Model ${ }^{2}$.

\begin{tabular}{cc}
\hline Item & Amount \\
\hline Milk price, NZ\$/kg milksolids & \\
NZ\$/kg Fat & 5.05 \\
NZ\$/kg Protein & 9.19 \\
NZ\$/L milk & -0.03 \\
Calves price, NZ\$/kg & 53.00 \\
Culled cow price, NZ\$ & 874.00 \\
Labour costs, NZ\$/h & 20.00 \\
Concentrate cost, NZ\$/t & 355.00 \\
Fertiliser: urea, NZ\$/t & 495.00 \\
\hline
\end{tabular}

${ }^{1}$ Season 2016-17. ${ }^{2}$ Shalloo et al. [14].

Table 4. Productive performance of two contrasting pasture-based dairy production systems in New Zealand.

\begin{tabular}{|c|c|c|c|c|c|c|}
\hline \multirow[b]{3}{*}{ Item } & \multicolumn{6}{|c|}{ Production System $^{1}$} \\
\hline & \multicolumn{3}{|c|}{ OAD-LI } & \multicolumn{3}{|c|}{ TAD-HI } \\
\hline & per cow & per ha & per farm & per cow & per ha & per farm \\
\hline Milk yield, $\mathrm{kg}$ & 4526 & 9693 & $1,163,175$ & 5910 & 16,510 & $1,518,890$ \\
\hline Milk solids yield, $\mathrm{kg}$ & 384 & 822 & 98,628 & 422 & 1179 & 108,491 \\
\hline Concentrate intake, $\mathrm{kg}$ DM & 27 & 58 & 7018 & 1723 & 4813 & 442,758 \\
\hline Crops intake, kg DM & 234 & 500 & 60,034 & 20 & 55 & 5023 \\
\hline Pasture grazed intake, $\mathrm{kg} \mathrm{DM}$ & 3594 & 7698 & 923,737 & 3286 & 9179 & 844,478 \\
\hline Fertiliser, $\mathrm{kg} \mathrm{N}$ & 62 & 134 & 16,050 & 31 & 87 & 8014 \\
\hline Pasture production, kg DM & 5675 & 14,584 & $1,458,405$ & 4811 & 13,572 & $1,236,441$ \\
\hline Pasture silage harvested, $\mathrm{kg} \mathrm{DM}$ & 347 & 891 & 89,100 & 157 & 443 & 40,300 \\
\hline Pasture utilised, kg DM & 3941 & 8589 & $1,012,837$ & 3443 & 9622 & 884,778 \\
\hline Pasture utilisation efficiency, \% & & 69 & & & 72 & \\
\hline
\end{tabular}

${ }^{1}$ Once-daily milking low intensity (OAD-LI); twice-daily milking high intensity (TAD-HI).

The cows in TAD-HI had 23\% higher DMI than the cows in OAD-LI, representing an extra $1384 \mathrm{~kg}$ of feed per cow annually (Table 4). Due to the increased SR in TAD-HI, this gap increased to an additional $41 \%$ of feed per ha ( $6817 \mathrm{~kg}$ of additional feed per ha). Only cows in TAD-HI had grain-based concentrate, which comprised $34 \%$ of the diet. The $0.7 \%$ of concentrate intake per cow in OAD-LI was allocated to calves and heifers. While cows in OAD-LI received $6 \%$ of their total diet as grazing crops, cows in TAD-HI only received $0.4 \%$ of diet as crops.

Notwithstanding the low input approach of OAD-LI, the application of $\mathrm{N}$ fertiliser was $54 \%$ higher than in TAD-HI. This represented an extra $46.6 \mathrm{~kg} \mathrm{~N}$ per ha (Table 4). Compared to TAD-HI, there was an additional $1012 \mathrm{~kg}$ DM mean pasture production per ha in OAD-LI. According to the different management approach, grazed pasture intake represented $89 \%$ and $60 \%$ of the total feed allowance throughout the year for OAD-LI and TAD-HI cows, respectively (Table 2). Considering the differences in SR, the grazed pasture per ha was 16\% higher in TAD-HI. Silage harvested in OAD-LI was 2-fold greater than in TAD-HI. Based on the management strategy and the milk yield observed in each system, the MDSM predicted $8589 \mathrm{~kg}$ DM of pasture per ha utilised in OAD-LI (grazed and harvested) and $9622 \mathrm{~kg}$ DM of pasture per ha utilised in TAD-HI. This represented a $69 \%$ and $72 \%$ of accumulated pasture utilisation efficiency in OAD-LI and TAD-HI, respectively (Table 4).

Milk sales represented approximately $93 \%$ of total income in both production systems (Table 5). Since TAD-HI had both a higher milk production per cow and a higher SR, an additional NZ\$2,776 per ha was received in income compared to OAD-LI. Total costs were considerably higher in TAD-HI, with an additional NZ\$2,379 per ha and NZ\$454 per cow compared to OAD-LI. Fertiliser costs represented 13\% of total costs in OAD-LI and 3\% in TAD-HI, translating to an additional NZ\$275 per ha in OAD-LI. On the other hand, 
purchased feed costs represented $28 \%$ of total costs in TAD-HI and only $1 \%$ in OAD-LI, translating to an additional NZ\$1,689 per ha and NZ\$602 per cow in TAD-HI. Including more crops in OAD-LI increased cropping costs by NZ\$217 per ha, compared to TAD-HI. Total costs relative to total milksolids production were $\mathrm{NZ} \$ 4.44$ per $\mathrm{kg}$ milksolids and NZ\$5.11 per kg milksolids in OAD-LI and TAD-HI, respectively reflecting the lower inputs included in OAD-LI. Moreover, these costs represented a higher operating profit per kg milksolids in OAD-LI (extra 0.42NZ\$ $/ \mathrm{kg}$ milksolids) but considering the higher SR and the superior milk yield of TAD-HI cows, the operating profit per ha was NZ\$398 higher in TAD-HI.

Table 5. Moorepark Dairy Systems Model ${ }^{1}$ financial performance output for two contrasting pasture-based dairy production systems in New Zealand.

\begin{tabular}{|c|c|c|c|c|c|c|}
\hline \multirow[b]{3}{*}{ Item } & \multicolumn{6}{|c|}{ Production System ${ }^{2}$} \\
\hline & \multicolumn{3}{|c|}{ OAD-LI } & \multicolumn{3}{|c|}{ TAD-HI } \\
\hline & per cow & per ha & per farm & per cow & per ha & per farm \\
\hline Milk sales, NZ\$ & 2476 & 5303 & 636,357 & 2843 & 7943 & 730,711 \\
\hline Livestock sales, NZ\$ & 188 & 402 & 48,296 & 193 & 539 & 49,618 \\
\hline Fertiliser costs, NZ\$ & 226 & 483 & 57,979 & 75 & 208 & 19,154 \\
\hline Purchased feed costs, NZ\$ & 10 & 21 & 2493 & 612 & 1710 & 157,289 \\
\hline Cropping and silage costs, NZ\$ & 166 & 356 & 42,751 & 50 & 139 & 12,795 \\
\hline Total costs ${ }^{3}, \mathrm{NZ} \$$ & 1703 & 3647 & 437,648 & 2157 & 6026 & 554,357 \\
\hline Operating profit, NZ\$ & 961 & 2058 & 247,004 & 879 & 2456 & 225,972 \\
\hline
\end{tabular}

${ }^{1}$ Shalloo et al. [14]. ${ }^{2}$ Once-daily milking low intensity (OAD-LI); twice-daily milking high intensity (TAD-HI). ${ }^{3}$ Only main costs are reported in this table.

\subsection{Effect of Production Systems on Cow Nitrogen Balance}

The annual $\mathrm{N}$ balance and NUE of the two production systems at the cow level are summarised in Table 6. From the total $\mathrm{N}$ intake, while the grazed pasture $\mathrm{N}$ intake represented $90 \%$ and $73 \%$ in OAD-LI and TAD-HI, respectively, the crops $\mathrm{N}$ intake accounted for $7 \%$ and $0.2 \%$ in OAD-LI and TAD-HI, respectively. Nitrogen intake included in concentrate only applied to the TAD-HI cows, and represented $19 \%$ of total N intake during the season. Despite the large difference between diets and DMI of the two production systems (Tables 1 and 2), total $\mathrm{N}$ intake per cow was similar, with a small difference of $3.5 \mathrm{~kg} \mathrm{~N}$ per cow, representing less than $0.06 \mathrm{~kg}$ of $\mathrm{CP}$ intake per cow per day throughout the year (Table 6). Milk $\mathrm{N}$ was the main component of total $\mathrm{N}$ output, with a difference of $12 \%$ in favour of the TAD-HI cows ( $4 \mathrm{~kg}$ extra milk $\mathrm{N}$ ) and this was followed by $\mathrm{N}$ in culled animals, with minor differences between production systems.

Table 6. Annual nitrogen $(\mathrm{N})$ balance per cow ( $\mathrm{kg} \mathrm{N} / \mathrm{cow})$ and $\mathrm{N}$ utilisation efficiency for two contrasting pasture-based dairy production systems in New Zealand generated by the $\mathrm{N}$ balance model ${ }^{1}$.

\begin{tabular}{ccc}
\hline & \multicolumn{2}{c}{ Production System $^{2}$} \\
\cline { 2 - 3 } Item & OAD-LI & TAD-HI \\
\hline Pasture grazed N intake & 107.9 & 90.6 \\
Silage kg N intake & 2.4 & 7.1 \\
Concentrate N intake & - & 23.9 \\
Crops N intake & 8.2 & 0.3 \\
Dairy cow replacement N & 1.9 & 1.9 \\
Total N intake & 120.4 & 123.8 \\
Milk N output & 29.0 & 33.0 \\
Live weight change N & 0.06 & 0.06 \\
Calf kg N output & 1.2 & 1.2 \\
\hline
\end{tabular}


Table 6. Cont.

\begin{tabular}{ccc}
\hline & \multicolumn{2}{c}{ Production System $^{2}$} \\
\cline { 2 - 3 } Item & OAD-LI & TAD-HI \\
\hline Cull cow N output & 2.8 & 2.9 \\
Total N output & 33.1 & 37.2 \\
N surplus & 87.3 & 86.7 \\
N utilisation efficiency, $\%$ & 27.5 & 30.0 \\
\hline${ }^{1}$ Ryan et al. [20]. ${ }^{2}$ Once-daily milking low intensity (OAD-LI); twice-daily milking high intensity (TAD-HI).
\end{tabular}

Nitrogen surplus was calculated by subtracting $\mathrm{N}$ output, including $\mathrm{N}$ contained in calf and cull cows plus milk $\mathrm{N}$, from $\mathrm{N}$ intake (which includes $\mathrm{N}$ intake of replacement cows). Results indicated a similar N surplus in OAD-LI and TAD-HI cows.

\subsection{Effect of Production System on Whole-Farm Nitrogen Balance}

The main sources of $\mathrm{N}$ input at the whole-farm level were feeds and fertiliser. In OAD$\mathrm{LI}$, fertiliser $\mathrm{N}$ represented $81 \%$, while $\mathrm{N}$ in feeds (only crops) represented $11 \%$, of total $\mathrm{N}$ inputs (Table 7). In contrast, $\mathrm{N}$ inputs in TAD-HI was comprised of $51 \%$ in fertilisers and $40 \%$ in concentrates. The higher reliance of directly-grazed pasture to feed OAD-LI cows is underpinned by higher $\mathrm{N}$ fertilisation levels, and this explains the greater contribution that fertiliser $\mathrm{N}$ made to $\mathrm{N}$ inputs in the OAD-LI. In the same manner, the feeding management strategy of TAD-HI explained the greater contribution that concentrate $\mathrm{N}$ made to $\mathrm{N}$ inputs.

Table 7. Annual whole-farm nitrogen $(\mathrm{N})$ balance ( $\mathrm{kg}$ of $\mathrm{N} / \mathrm{ha}$ ) and $\mathrm{N}$ utilisation efficiency for two contrasting pasture-based dairy production systems in New Zealand generated by the $\mathrm{N}$ balance model ${ }^{1}$.

\begin{tabular}{ccc}
\hline & \multicolumn{2}{c}{ Production System ${ }^{2}$} \\
\cline { 2 - 3 } Item & OAD-LI & TAD-HI \\
\hline Concentrate N consumed & - & 67.5 \\
Crops N consumed & 17.6 & 0.8 \\
Fertiliser N & 133.8 & 87.1 \\
N input in the replacement cows & 4.0 & 5.4 \\
N atmospheric deposition & 9.0 & 9.0 \\
Total N inputs & 164.4 & 169.8 \\
Milk N & 56.3 & 83.6 \\
Live weight change N & 0.12 & 0.16 \\
Calf N & 2.2 & 2.9 \\
Cull cow N & 4.7 & 6.3 \\
Total N output & 63.3 & 93.0 \\
Soil N Mineralisation & 81.7 & 78.1 \\
N surplus & 101.0 & 76.8 \\
N utilisation efficiency, $\%$ & 26 & 38 \\
\hline
\end{tabular}

${ }^{1}$ Ryan et al. [20]. ${ }^{2}$ Once-daily milking low intensity (OAD-LI); twice-daily milking high intensity (TAD-HI). Note: Does not include the $\mathrm{N}$ lost associated with grain production and crop growth.

Total $\mathrm{N}$ input of TAD-HI was $3 \%$ higher than OAD-LI. This equated to an additional $5.4 \mathrm{~kg} \mathrm{~N}$ per ha more in TAD-HI, but this was offset by an even larger $\mathrm{N}$ output, which was $29.7 \mathrm{~kg}$ N per ha higher than OAD-LI. In the case of OAD-LI, N surplus and NUE at the whole-farm scale was largely affected by the lower $\mathrm{N}$ output relative to TAD-HI, specifically, milk $\mathrm{N}$ reflecting the reduction in milk production effect as a consequence of milking the cows OAD and feeding a less energy-dense diet throughout the season (Table 2).

The difference between the concentrate $\mathrm{N}$ in TAD-HI and the fertiliser N in OAD-LI was not sufficient to offset the difference between $\mathrm{N}$ outputs, particularly milk $\mathrm{N}$, and this resulted in a larger $\mathrm{N}$ surplus in OAD-LI and in a greater NUE in TAD-HI. Compared to 
the $\mathrm{N}$ surplus and NUE at the cow level, in the whole-farm $\mathrm{N}$ balance the differences were increased by including the fraction of $\mathrm{N}$ fertiliser.

Environmental $\mathrm{N}$ losses are summarised in Table 8. Total $\mathrm{N}$ excreta per ha was $24 \%$ lower in OAD-LI due to the lower SR. There was not much difference between production system in faecal $\mathrm{N}$ per ha, however urinary $\mathrm{N}$ per ha was $28 \%$ higher in TAD-HI, essentially following the increase in DMI of TAD-HI cows along with the higher SR of this production system (Table 1). As the $\mathrm{N}$ surplus increased from TAD-HI to OAD-LI, so too did the quantity of $\mathrm{N}$ available for leaching, representing 81.4 and $54.1 \mathrm{~kg} \mathrm{~N}$ per ha in OAD-LI and TAD-HI, respectively.

Table 8. Annual nitrogen (N) losses ( $\mathrm{kg}$ of $\mathrm{N} / \mathrm{ha}$ ) for two contrasting pasture-based dairy production systems in New Zealand generated by the $\mathrm{N}$ balance model ${ }^{1}$.

\begin{tabular}{ccc}
\hline & \multicolumn{2}{c}{ Production System $^{2}$} \\
\cline { 2 - 3 } Item & OAD-LI & TAD-HI \\
\hline N excreta in dung & 31.4 & 32.4 \\
N excreta in urine & 121.5 & 168.2 \\
Ammonia emissions & 13.3 & 14.7 \\
N available for leaching & 81.4 & 54.1 \\
\hline
\end{tabular}

${ }^{1}$ Ryan et al. [18]. ${ }^{2}$ Once-daily milking low intensity (OAD-LI); twice-daily milking high intensity (TAD-HI) Note: Does not include the $\mathrm{N}$ lost associated with grain production and crop growth.

\section{Discussion}

The present study reports the efficiency of $\mathrm{N}$ utilisation along with the physical and economic performance of two systems operating with differing milking frequencies and levels of intensity. While the herd composition was different between herds in terms of breed composition, the similar BW between cows in each herd makes them comparable in terms of genetic merit. The contiguous location of these two research farms confirms that cows and paddocks on both farms were exposed to the same climatic and environmental conditions throughout the production season. However, the management of the farms were different. The OAD-LI farm was based on pasture grazed directly with low levels of supplementation in combination with lower SR and cows milked OAD. In comparison, the TAD-HI system had a 25\% higher SR with cows milked TAD along with higher supplementation and lower reliance on pasture. Consequently, this dataset offered a unique opportunity to investigate different aspects of both biological and economic performance along with NUE and N losses of different intensification levels of pasture-based production systems on a farm system scale. Caution is required when interpreting these modelled $\mathrm{N}$ efficiencies and losses results, given that no validation was undertaken. It should also be noted that the results combine the effect of system intensity and milking frequency and therefore the individual effects of either cannot be determined. Lastly, results presented are at the dairy farm gate, and if a full system boundary analysis was completed, different conclusions might be arrived at.

\subsection{Efficiency of Nitrogen Utilisation at the Cow Level}

In OAD-LI, NUE at a cow level was lower than in TAD-HI and this was caused by less $\mathrm{N}$ captured in milk as a consequence of lower milk yield with a correspondent reduction in protein yield. Considering that both herds are of comparable and high genetic merit, the reduction in milk yield was due to the reduced milking frequency in OAD-LI. By reducing the milking frequency from TAD to OAD, Delamaire and Guinard-Flament [24] reported a drop of nutrient uptake in the mammary gland which negatively affected the milk production of cows in peak lactation. Other studies have reported varied NUE at a cow level in New Zealand under grazing conditions with different levels of concentrate inclusion. For example, Totty et al. [25] observed NUE at a cow level of 17, 16, and 19\% in midlactation cows grazing solely ryegrass/white clover pasture, high-sugar ryegrass/white clover pasture and high-sugar ryegrass/white clover pasture with chicory and plantain, 
respectively. In addition, Al-Marashdeh et al. [26] observed NUE of 20 and 23\% in latelactation cows fed ryegrass/white clover pasture and ryegrass/white clover pasture with $3 \mathrm{~kg}$ DM per cow of maize silage supplementation, respectively. The NUE reported in the present study was higher than the NUE figures reported by Totty et al. [25] and by Al-Marashdeh et al. [26], because cows of TAD-HI were fed lower protein supplements. Additionally, our measurements of NUE were calculated including total $\mathrm{N}$ in milk and other outputs such as LW change, calf $\mathrm{N}$ output, and cull cow $\mathrm{N}$ output (Table 6). In turn, the differences estimated in NUE among OAD-LI and TAD-HI in the present study, were comparable to the differences in NUE of New Zealand cows fed higher proportions of concentrate relative to grass-based diets in the study reported by Ryan et al. [20].

Lower dietary $\mathrm{CP}$ content and higher intake of the TAD-HI compared to the OAD-LI system (Tables 1 and 2), resulted in 3\% higher $\mathrm{N}$ intake in TAD-HI (124 $\mathrm{kg} \mathrm{N}$ intake/cow) compared to OAD-LI (120 kg N intake/cow). Bargo et al. [27] reported a similar outcome on cows grazing pastures at different allowance levels with and without concentrate supplementation, and showed that the supplemented cows with concentrate (of lower $\mathrm{CP}$ ) increased their DMI and substituted a portion of offered pasture, and this resulted in similar CP intake levels among treatments. In the present study, the closeness in $\mathrm{N}$ intake between production systems was explained by the higher intake of a diet lower in $\mathrm{CP}$ in TAD-HI when compared to OAD-LI.

Diluting the often high $\mathrm{N}$ contained in directly grazed pastures with low- $\mathrm{N}$ energyenriched supplement is described as a strategy to provide more energy for microbes to increase microbial protein synthesis [28]. Reed et al. [29] reported that there is an extra energetic cost spent in eliminating the excess $\mathrm{N}$ from cows fed with diets exceeding the $\mathrm{CP}$ requirements for milk production. In the case of OAD-LI, milk production was suppressed and diet was higher in CP throughout the season. Consequently, the higher NUE observed in TAD-HI cows in the present study was explained by the increased milk yield due to the higher milking frequency and by feeding a more balanced ration in terms of the energy:protein ratio (Table 2) [26,27].

\subsection{Efficiency of Nitrogen Utilisation at the Whole-Farm Level}

Utilising the same models of farm efficiency and $\mathrm{N}$ balance, an Irish study of pastured TAD cows comparing performance of high producing, high durability and New Zealand strains with diverse levels of supplementation and SR by Ryan et al. [20] reported a mean NUE of $31 \%$. A farmlet study by Roche et al. [30] in New Zealand, measured a mean NUE of $35 \%$ on TAD cows with SR ranging from 2.2 to 4.3 cows per ha. Allowing the comparison of these two research approaches (modelling vs. farmlet studies), the efficiencies observed by Roche et al. [30], along with those observed by Ryan et al. [20] were lower compared to the NUE modelling predictions from the present study, because of the lower N fertiliser employed in TAD-HI in comparison with these other studies. Rates of $\mathrm{N}$ fertiliser applied annually were $200 \mathrm{~kg}$ per ha [30] and $275 \mathrm{~kg}$ per ha [20], compared with $87 \mathrm{~kg}$ per ha in the present study. In the same manner, by applying an additional $35 \%$ of $\mathrm{N}$ fertiliser in OAD-LI, which was the principal $\mathrm{N}$ input in this system, the $\mathrm{N}$ surplus was increased by $24 \mathrm{~kg} \mathrm{~N}$ per ha and the NUE was reduced by 31\% (Table 7). Based on the low pasture utilisation from the present study, it could be strongly argued that the pasture (and N) was surplus to requirements and that there is significant potential to increase the NUE within each system with higher utilisation of the pasture grown (Table 4) and this is particularly the case on OAD-LI. A recent farmlet study by Clark et al. [31] reported that increasing pasture utilisation efficiency from $78 \%$ to $87 \%$ resulted in a $43 \%$ reduction of $\mathrm{N}$ losses through better NUE. The improvement in pasture utilisation efficiency was achieved by adjusting $\mathrm{N}$ fertiliser ( $75 \mathrm{~kg} \mathrm{~N}$ fertiliser less per ha) to target feed grown according to the feed demand of the two systems compared in their study. One must be cognisant that there will be $\mathrm{N}$ losses associated with production of the extra feed and that the total $\mathrm{N}$ losses would be higher if the system boundary was expanded to the inclusion of the crop growth It is also worth noting that the present study was not designed as a control/treatment type 
study and therefore the overall conclusions from the production data need to be interpreted within that context.

\subsection{Nitrogen Losses from the Production Systems}

On a whole-farm level, $\mathrm{N}$ surplus indicates potential losses of $\mathrm{N}$ to the environment, but the internal flows including $\mathrm{N}$ captured in pasture production, pasture harvested by cows and $\mathrm{N}$ disappearing from herbage to litter are not taken into account in the calculation of the $\mathrm{N}$ surplus at the paddock level [6]. The $\mathrm{N}$ surplus (i.e., total inputs minus total outputs) is a key indicator that can be directly linked to $\mathrm{N}$ losses from the system, but caution must be taken when comparing between production systems with different characteristics, considering that the relationship between $\mathrm{N}$ surplus and $\mathrm{N}$ leaching can change for different scenarios [6,32].

Whereas Ryan et al. [20] observed an average relationship of $66 \%$ of $\mathrm{N}$ available for leaching from total $\mathrm{N}$ surplus, this relationship in the present study was $81 \%$ and $70 \%$ for OAD-LI and TAD-HI, respectively. Consequently, it is not easy to compare the $\mathrm{N}$ surplus from one study to another [6,32]. Agreement is required on which items should be included in the input and output terms and a number of site-specific factors (e.g., soil, climate) will also affect the $\mathrm{N}$ cycle and the $\mathrm{N}$ captures and losses from the system [32].

The main losses of $\mathrm{N}$ from a dairy grazing system occur through denitrification, volatilisation and leaching [33]. Ammonia volatilisation losses originate from excreta (mainly urine) and from $\mathrm{N}$ fertilisation [5]. Contrary to the positive relation of volatilisation and $\mathrm{N}$ fertiliser applications observed by Ledgard et al. [5], the same relationship was not observed in the present study, with similar losses of ammonia across both production systems. The positive relationship between volatilisation and fertilisation reported by Ledgard et al. [5] may have been due to the contrasting rates of $\mathrm{N}$ fertilisers of their study. While Ledgard et al. [5] utilised from nil to 225,360 and $430 \mathrm{~kg} \mathrm{~N}$ per ha per annum, in the present study the fertiliser rates ranged from 87 in TAD-HI to $135 \mathrm{~kg} \mathrm{~N}$ per ha in OAD-LI. Both production systems scenarios applied less than $150 \mathrm{~kg} \mathrm{~N}$ per ha per year, the level at which the balance between food production and environmental outcomes appears to be optimised [7].

The increase in imported bought-in feeds and $\mathrm{N}$ fertiliser usage are usually associated with increased SR to improve productivity, but are likely to increase $\mathrm{N}$ available for losses to the environment [7]. Nitrogen fertilisation has a large impact on $\mathrm{N}$ losses from both the animal and the farm as it is involved in many processes within the $\mathrm{N}$ cycle $[5,6]$. Despite the positive effect of its use on pasture production, the efficiency with which it is used is variable [33] and, similar to feed supplementation, depends on the response of the extra milk produced in relation to the extra kg pasture grown. A study conducted by Shepherd et al. [34] found that a $20 \%$ reduction in SR along with less $\mathrm{N}$ fertiliser applied resulted in $14 \%$ less urinary $\mathrm{N}$ excreted per ha per day, due to a decrease in $\mathrm{N}$ consumed per ha. In contrast, on a whole-farm level study in Ireland undertaken by McCarthy et al. [35], there was an increase in measured $\mathrm{N}$ losses (including nitrites, nitrates and ammonia) from free-draining soils where lower SR resulted in less utilisation of grazed pasture. The increase in $\mathrm{N}$ fertiliser applied in OAD-LI was associated with $1260 \mathrm{~kg}$ DM per ha of additional pasture production, but because there were less cows available to utilise this extra feed grown, this resulted in a lower response in milk per $\mathrm{kg}$ of $\mathrm{N}$ applied and an additional $27.3 \mathrm{~kg} \mathrm{~N}$ per ha available for leaching in. In reality, this system should have been run with a lower fertiliser $\mathrm{N}$ level, as the extra pasture growth was not utilised.

\subsection{Physical and Economic Performance}

Despite the relatively low operating cost of running temperate grass-based dairy systems, the land is the main capital component and is becoming a limiting resource for the dairy farming sector [36]. The optimum production system is that which returns the maximum income per unit of limiting resource. Consequently, a prudent strategy would be to dilute the cost of the land by increasing milk production per area [36] which has occurred 
in New Zealand through intensifying the dairy systems since the 1990's [36,37]. On the other hand, it is still debated which grade of inclusion of inputs (fertilisers, bought-in feeds) should be included as these would have a great impact on farming costs [36]. Research from Ireland [38] has shown that for each additional 10\% increase in bought-in feed, there was a reduction in operating profit per hectare by $€ 97$.

The study conducted by Edwards [8] to explore profitability of milking herds milked OAD vs TAD within New Zealand, reported an additional $25 \%$ in total farming costs per ha from stabilised herds milked TAD. In the present study, the gap between OAD-LI and TAD-HI was $39 \%$ in total costs per ha. The total costs per $\mathrm{kg}$ milksolids for OAD-LI were $8 \%$ lower than for TAD-HI (NZ\$4.41 and NZ\$4.79, respectively). The costs per kg of milksolids for OAD-LI were similar to the data reported by Edwards [8]. Feed costs per ha of TAD-HI were $44 \%$ higher (extra NZ\$766 per ha) than feed costs from farms representing a typical system in the Waikato basin ('current') from 2000 to 2010 [31]. It must be considered that procedures in which costs are calculated (or estimated) are not always consistent and this might lead to biased comparisons [37].

With an additional 5\% kg MS per ha from OAD-LI compared to the stabilised full season OAD milking herd reported by Edwards [8], operating (net) profit was 19\% greater in OAD-LI compared to Edwards [8]. The operating profit from TAD-HI was 15\% higher than the profit from 'current' farms reported by Clark et al. [31]. Higher input systems can provide more consistent milk yield but they are more complex to manage, and risk may be higher if variability in feed and milk prices is not controlled [37]. Interestingly, the operating profit from the 'current' farms of the Waikato region reported by Clark et al. [31] was similar to the OAD-LI farm. This might be relevant for farmers who are considering adopting full season OAD milking. In agreement with Edwards [8], profitability can be achieved by adopting full season OAD milking, but in order to improve the operating profit of the business, the farm operation must be restructured to reduce costs.

Reducing the milking frequency in OAD-LI resulted in a drop in milk yield and DMI per cow and per ha [9]. The reduced SR of the OAD-LI farm resulted in a lower feed demand per ha [35], and an increase in $\mathrm{N}$ fertiliser usage increased pasture production [33] and this led to a decline in pasture utilised. In reality it is clear that without environmental restrictions, many OAD systems would operate at a higher stocking rate to increase feed demand and therefore pasture utilisation. In the present study, the decline in pasture utilised per hectare with a low SR and/or increased use of purchased supplements was responsible for the low input response (fertilisers, supplements, irrigation) along with an increase in associated costs of growing unutilised pasture in conjunction with increased fixed costs. These settings were associated with reductions of the operating profitability of pasture-based dairy systems [36,39]. On a large dataset from the Irish National Farm Survey including a selection of 257 dairy farms of contrasting productive scenarios over a period of 8 consecutive years, Hanrahan et al. [38] demonstrated that pasture utilisation per ha is a crucial measurement of farm efficiency. This last study cited recognised that by determining appropriate SR, grazing seasonal length and proportion of purchased feeds among other factors, the overall farm performance would be maximised. Chapman et al. [40] observed that by reducing inputs of $\mathrm{N}$ fertiliser and supplementation, there is margin to maximise profitability and reduce the environmental footprint on systems, but it must be ensured that SR is aligned with the feed demand and feed offered on farms.

\section{Conclusions}

The present research investigated the differences in productivity, profitability and some environmental consequences between two contrasting pasture-based dairy farming systems of New Zealand differing in milking frequency and intensification level. On a cow level, a similar gap between $\mathrm{N}$ inputs and outputs of both systems explained the equal $\mathrm{N}$ surplus, but the NUE was better in the TAD-HI production system reflecting a more balanced diet in terms of $\mathrm{CP}$ and energy. The whole-farm simulation showed a larger $\mathrm{N}$ surplus in OAD-LI as a result of similar $\mathrm{N}$ inputs but with reduced $\mathrm{N}$ output captured 
in milk. This represented a lower NUE in OAD-LI and increased the N available for loss. Despite the higher costs of milk production in TAD-HI, its operating profit was superior as a consequence of milking more cows that produced higher milk yield compared to cows of OAD-LI. However, at a low milk price the TAD-HI would come under more pressure faster, as a result of higher costs. These results suggest that milking frequency, the use of feed supplementation and application of $\mathrm{N}$ fertiliser as management tools on grazing dairy systems affect productivity, profitability and $\mathrm{N}$ balance. Further studies are required to find optimal stocking rates in combination with the use of supplementary feed and $\mathrm{N}$ fertiliser application that maximise milk production and profitability for OAD and TAD milking production systems but minimise $\mathrm{N}$ losses.

Author Contributions: Conceptualization: M.C.-L., D.D., P.K., L.S., E.R., D.H. and N.L.-V.; methodology: M.C.-L., D.D., P.K., L.S., D.H. and N.L.-V.; formal analysis: M.C.-L., L.S., E.R. and N.L.-V.; investigation: M.C.-L.; resources: D.D., P.K., L.S. and N.L.-V.; data curation: M.C.-L., L.S. and N.L.-V.; writing-original draft preparation: M.C.-L.; writing-review and editing: M.C.-L., D.D., P.K., L.S. and N.L.-V.; funding acquisition: D.D., P.K. and N.L.-V. All authors have read and agreed to the published version of the manuscript.

Funding: This research received no external funding.

Institutional Review Board Statement: Not applicable.

Informed Consent Statement: Not applicable.

Data Availability Statement: Data is contained within the article.

Acknowledgments: The principal author acknowledges the assistance from Colin Holmes Dairy Scholarship, George Mason Sustainable Land Use Scholarship and the Cecil Elliot Trust of New Zealand. Special thanks to Associate Professor in Soil Science David Horne for his advice and to Fiona Sharland from Massey Agricultural Experiment Station for providing management data from the research farms studied.

Conflicts of Interest: The authors declare no conflict of interest.

\section{References}

1. Waghorn, G.C.; Clark, D.A. Feeding value of pastures for ruminants. N. Z. Vet. J. 2004, 52, 320-331. [CrossRef] [PubMed]

2. Tilman, D.; Cassman, K.G.; Matson, P.A.; Naylor, R.; Polasky, S. Agricultural sustainability and intensive production practices. Nature 2002, 418, 671-677. [CrossRef]

3. Ventura, B.A.; von Keyserlingk, M.A.G.; Wittman, H.; Weary, D. M. What difference does a visit make? Changes in animal welfare perceptions after interested citizens tour a dairy farm. PLOS ONE 2016, 11, e0154733. [CrossRef]

4. Kolver, E.S.; Muller, L.D. Performance and nutrient intake of high producing Holstein cows consuming pasture or a total mixed ration. J. Dairy Sci. 1998, 81, 1403-1411. [CrossRef]

5. Ledgard, S.F.; Penno, J.W.; Sprosen, M.S. Nitrogen inputs and losses from clover/grass pastures grazed by dairy cows, as affected by nitrogen fertilizer application. J. Agric. Sci. 1999, 132, 215-225. [CrossRef]

6. Peyraud, J.L.; Delaby, L. Grassland management with emphasis on nitrogen flows. In Fresh Herbage for Dairy Cattle, Elgersma, A.; Dijkstra, J., Tamminga, S., Eds.; Springer: Amsterdam, The Netherlands, 2006; pp. 103-123.

7. Parsons, A.; Thornley, J.H.M.; Rasmussen, S.; Rowarth, J.S. Some clarification of the impacts of grassland intensification on food production, nitrogen release, greenhouse gas emissions and carbon sequestration: Using the example of New Zealand. CAB Rev. 2016, 11. [CrossRef]

8. Edwards, J.P. A comparison of profitability between farms that milk once or twice a day. Anim. Prod. Sci. 2018, 60, an18528. [CrossRef]

9. Stelwagen, K.; Phyn, C.V.C.; Davis, S.R.; Guinard-Flament, J.; Pomiès, D.; Roche, J.R.; Kay, J.K. Invited review: Reduced milking frequency: Milk production and management implications. J. Dairy Sci. 2013, 96, 3401-3413. [CrossRef]

10. Clark, D.A.; Phyn, C.V.; Tong, M.J.; Collis, S.J.; Dalley, D.E. A systems comparison of once- versus twice-daily milking of pastured dairy cows. J. Dairy Sci. 2006, 89, 1854-1862. [CrossRef]

11. Lynch, G.A.; Hunt, M.E.; MacKenzie, D.D.S. The effects of once daily milking as a management practice in late lactation. Proc. N. Z. Soc. Anim. Prod. 1991, 51, 191-195.

12. Chobtang, J.; Sneddon, N.W.; McLaren, S.J.; Donaghy, D.J.; López-Villalobos, N.; Correa-Luna, M.; Ledgard, S. Environmental Evaluation of Once-a-Day Milking on a Pasture-Based Dairy System in New Zealand; Massey University: Palmerston North, New Zealand, 2018; p. 6. 
13. Correa-Luna, M.; Donaghy, D.; Kemp, P.; Schutz, M.; López-Villalobos, N. Efficiency of Crude Protein Utilisation in Grazing Dairy Cows: A Case Study Comparing Two Production Systems Differing in Intensification Level in New Zealand. Animals 2020, 10, 1036. [CrossRef]

14. Shalloo, L.; Dillon, P.; Rath, M.; Wallace, M. Description and Validation of the Moorepark Dairy System Model. J. Dairy Sci. 2004, 87, 1945-1959. [CrossRef]

15. DairyNZ. Facts \& Figures; DairyNZ: Hamilton, New Zealand, 2017.

16. DairyNZ. Economic Values. Available online: https://www.dairynz.co.nz/animal/animal-evaluation/interpreting-the-info/ economic-values (accessed on 15 April 2020).

17. L'Huillier, P.J.; Thomson, N.A. Estimation of herbage mass in ryegrass/white clover dairy pastures. Proc. N. Z. Soc. Anim. Prod. 1988, 49, 117-122. [CrossRef]

18. Baker, R.D. Estimating herbage intake from animal performance. In Herbage Intake Handbook, 2nd ed.; British Grassland Society: London, UK, 2004; p. 191.

19. Corson, D.C.; Waghorn, G.C.; Ulyatt, M.J.; Lee, J. NIRS: Forage analysis and livestock feeding. Proc. N. Z. Grassl. Assoc. 1999, 61, 127-132. [CrossRef]

20. Ryan, W.; Hennessy, D.; Murphy, J.J.; Boland, T.M.; Shalloo, L. A model of nitrogen efficiency in contrasting grass-based dairy systems. J. Dairy Sci. 2011, 94, 1032-1044. [CrossRef] [PubMed]

21. Del Prado, A.; Brown, L.; Schulte, R.; Ryan, M.; Scholefield, D. Principles of development of a mass balance N cycle model for temperate grasslands: An Irish case study. Nutr. Cycl. Agroecosyst. 2006, 74, 115-131. [CrossRef]

22. Misselbrook, T.; Chadwick, D.; Chambers, B.; Smith, K.; Webb, J.; Demmers, T.; Sneath, R. Inventory of Ammonia Emissions from UK Agriculture 2004; Defra: London, UK, 2006.

23. Jarrige, R.; Demarquilly, C.; Dulphy, J.P.; Hoden, A.; Robelin, J.; Beranger, C.; Geay, Y.; Journet, M.; Malterre, C.; Micol, D.; et al. The INRA "fill unit" system for predicting the voluntary intake of forage-based diets in ruminants: A review. J. Anim. Sci. 1986, 63, 1737-1758. [CrossRef]

24. Delamaire, E.; Guinard-Flament, J. Increasing milking intervals decreases the mammary blood flow and mammary uptake of nutrients in dairy cows. J. Dairy Sci. 2006, 89, 3439-3446. [CrossRef]

25. Totty, V.K.; Greenwood, S.L.; Bryant, R.H.; Edwards, G.R. Nitrogen partitioning and milk production of dairy cows grazing simple and diverse pastures. J. Dairy Sci. 2013, 96, 141-149. [CrossRef] [PubMed]

26. Al-Marashdeh, O.; Gregorini, P.; Edwards, G.R. Effect of time of maize silage supplementation on herbage intake, milk production, and nitrogen excretion of grazing dairy cows. J. Dairy Sci. 2016, 99, 7123-7132. [CrossRef]

27. Bargo, F.; Muller, L.D.; Delahoy, J.E.; Cassidy, T.W. Milk response to concentrate supplementation of high producing dairy cows grazing at two pasture allowances. J. Dairy Sci. 2002, 85, 1777-1792. [CrossRef]

28. Mulligan, F.J.; Dillon, P.; Callan, J.J.; Rath, M.; O’Mara, F.P. Supplementary concentrate type affects nitrogen excretion of grazing dairy cows. J. Dairy Sci. 2004, 87, 3451-3460. [CrossRef]

29. Reed, K.F.; Bonfa, H.C.; Dijkstra, J.; Casper, D.P.; Kebreab, E. Estimating the energetic cost of feeding excess dietary nitrogen to dairy cows. J. Dairy Sci. 2017, 100, 7116-7126. [CrossRef] [PubMed]

30. Roche, J.R.; Ledgard, S.F.; Sprosen, M.S.; Lindsey, S.B.; Penno, J.W.; Horan, B.; Macdonald, K.A. Increased stocking rate and associated strategic dry-off decision rules reduced the amount of nitrate-N leached under grazing. J. Dairy Sci. 2016, 99, 5916-5925. [CrossRef]

31. Clark, D.A.; Macdonald, K.A.; Glassey, C.B.; Roach, C.G.; Woodward, S.L.; Griffiths, W.M.; Neal, M.B.; Shepherd, M.A. Production and profit of current and future dairy systems using differing nitrogen leaching mitigation methods: The Pastoral 21 experience in Waikato. N. Z. J. Agric. Res. 2019, 63, 1-24. [CrossRef]

32. De Klein, C.A.M.; Monaghan, R.M.; Alfaro, M.; Gourley, C.J.P.; Oenema, O.; Powell, J.M. Nitrogen performance indicators for dairy production systems. Soil Res. 2017, 55, 479-488. [CrossRef]

33. Whitehead, D.C. Grassland Nitrogen; CAB International: Wallingford, UK, 1995.

34. Shepherd, M.; Shorten, P.; Costall, D.; Macdonald, K.A. Evaluation of urine excretion from dairy cows under two farm systems using urine sensors. Agric. Ecosyst. Environ. 2017, 236, 285-294. [CrossRef]

35. McCarthy, J.; Delaby, L.; Hennessy, D.; McCarthy, B.; Ryan, W.; Pierce, K.M.; Brennan, A.; Horan, B. The effect of stocking rate on soil solution nitrate concentrations beneath a free-draining dairy production system in Ireland. J. Dairy Sci. 2015, 98, 4211-4224. [CrossRef] [PubMed]

36. Macdonald, K.A.; Penno, J.W.; Lancaster, J.A.S.; Bryant, A.M.; Kidd, J.M.; Roche, J.R. Production and economic responses to intensification of pasture-based dairy production systems. J. Dairy Sci. 2017, 100, 6602-6619. [CrossRef]

37. Shadbolt, N.M. Competitive strategy analysis of New Zealand pastoral dairy farming systems. Int. J. Agric. Manag. 2012, 1, 19-27.

38. Hanrahan, L.; Geoghegan, A.; O’Donovan, M.; Griffith, V.; Ruelle, E.; Wallace, M.; Shalloo, L. PastureBase Ireland: A grassland decision support system and national database. Comput. Electron. Agric. 2017, 136, 193-201. [CrossRef]

39. Wales, W.J.; Kolver, E.S. Challenges of feeding dairy cows in Australia and New Zealand. Anim. Prod. Sci. 2017, 57, 1366-1383. [CrossRef]

40. Chapman, D.; Edwards, G.; Dalley, D.; Cameron, K.; Di, H.; Bryant, R.; Romera, A.; Clement, A.; Malcolm, B.; Curtis, J. Nitrogen Leaching, Production and Profit of Irrigated Dairy Systems Using Either Low or High Inputs of Fertiliser and Feeds: The Pastoral 21 Experience in Canterbury; Occasional Report No. 30. Fertilizer and Lime Research Centre; Massey University: Palmerston North, New Zealand, 2017. 